\title{
Pengembangan Lembar Kerja Peserta Didik (LKPD) Berbasis Inkuiri Pada Materi Pengklasifikasian Ikan
}

\author{
Yulia Anita ${ }^{1}$, Saleh Hidayat ${ }^{2}$, Haryadi ${ }^{3}$ \\ 1,2,3 Universitas Muhammadyah Palembang, Indonsia
}

Corresponding Author: Yulia Anita, E-mail: yuliaanita.88@gmail.com

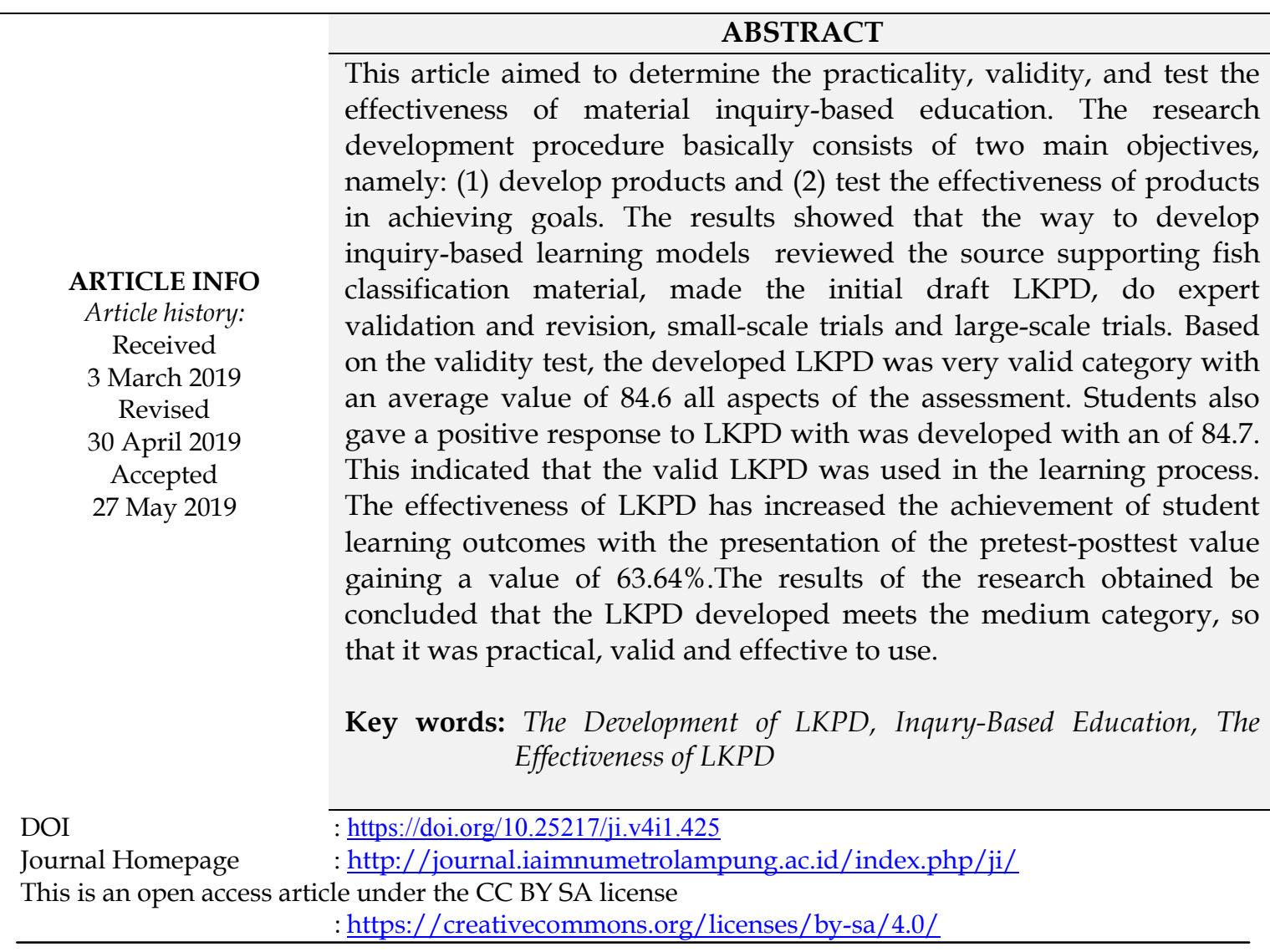

\section{PENDAHULUAN}

Pembelajaran merupakan interaksi belajar-mengajar antara guru dan siswa untuk mendorong perilaku belajar siswa yang merupakan proses belajar yang dialami oleh siswa menuju pada suatu target yang telah ditetapkan sebelumnya (Dimyati, 1999). Pembelajaran pada dasarnya adalah rekayasa untuk membantu siswa agar dapat tumbuh berkembang sesuai dengan tujuannya dan tidak hanya berinteraksi dengan guru sebagai satu-satunya sumber belajar, melainkan berinteraksi dengan semua sumber belajar yang mungkin dapat dipakai untuk mencapai hasil pembelajaran yang diinginkan (Abdul, 2008). 
Berdasarkan uraian di atas dapat disimpulkan bahwa pembelajaran adalah usaha seorang guru untuk mengarahkan dan membimbing interaksi atau proses belajar siswa dengan sumber belajarnya untuk mencapai tujuan yang diharapkan. Guru juga harus menyediakan sumber belajar yang memungkinkan siswa dapat terlibat secara aktif dalam proses belajar.

Kegiatan pembelajaran di kelas tidak bisa dilepaskan dari adanya media pembelajaran, karena dalam melancarkan kegiatan pembelajaran dan meningkatkan kemampuan berpikir serta kecerdasan siswa tentunya harus diimbangi dengan penyediaan media pembelajaranyang baik. Hal ini sangat dibutuhkan oleh para guru maupun siswa dalam membantu kegiatan pembelajaran di sekolah. Kurang lengkapnya media pembelajaran di sekolah dapat menghambat kegiatan pembelajaran, keadaan tersebut akan mempengaruhi hasil belajar siswa.

Rendahnya kualitas pendidikan biologi juga tampak di sekolah-sekolah di Banyuasin III. Hasil observasi dan wawancara langsung dengan beberapa orang guru biologidi SMA Negeri Banyuasin III mengidentifikasi bahwa, (1) empat guru menyatakan bahwa kegiatan pembelajaran masih cenderung bersifat konvensional yang didominasi dengan metode ceramah dan tanya jawab, guru masih menggunakan pembelajaran langsung yang cenderung hanya mengasah kemampuan mengingat (remembering) dan memahami (understanding), yang merupakan kemampuan berpikir tingkat rendah (low order ofthinking); (2) dua guru menyatakan bahwa proses pembelajaran selama ini belum melatih siswa untuk berpikir kritis sehingga siswa kurang memiliki kemampuan berpikir kritis; (3)empat guru menyebutkan bahwa aktivitas siswa dalam pembelajaran masih rendah, siswa cenderung masih sebagai pendengar yang bersifat pasif dan siswa kurang memiliki kepercayaan diri (self efficacy) yang baik.

Kurikulum 2013 penggunaan pendekatan saintifik dalam proses pembelajaran sebagaimana tercantum dalam permendiknas nomor 65 tahun 2013 tentang standar proses (Kemendikbud, 2013). Agar siswa dapat meningkatkan penguasaan konsep dan sikap peduli lingkungan, guru sebagai fasilitator harus merancang penerapan model kegiatan pembelajaran, yang mengarahkan siswa melakukan penyelidikan. Untuk mendukung proses pembelajaran yang demikian, maka dalam penelitian ini penerapan model inkuiri akan dikemas dalam suatu perangkat pembelajaran yang meliputi silabus, RPP, LKPD dan instrumen penilaian. Dalam pembelajaran pada umumnya guru sudah mengarahkan siswa untuk mengembangkan keterampilan berfikir kritis, tetapi dalam beberapa kegiatan guru cenderung masih menggunakan metode konvensial dalam pembelajaran. Hal tersebut 
sesuai dengan hasil angket siswa bahwa 83\% siswa menyatakan dalam pembelajaran biologi guru lebih sering menggunakan metode konvensial, selain itu bahan ajar yang digunakan di SMA Negeri 1 Banyuasin III dan SMA Negeri 3 Banyuasin III hanya menggunakan LKPD biologi SMA/MA dari percetakan yang berisi materi dan latihan soal, belum ada yang berbasis inkuiri.

Pada kenyataanya ketercapaian kompetensi siswa yang diharapkan pada tujuan pembelajaran biologi dalam pelaksanaan pembelajaran di sekolah masih kurang diperhatikan, kususnya di SMA Negeri 1 Banyuasin III, dan SMA Negeri 3 Banyuasin III. Terlihat dalam proses pembelajaran LKPD yang digunakan siswa masih belum menggunakan pendekatan berbasis inkuiri, dengan menggunakan LKPD tersebut pemberian praktikum dan dilanjutkan dengan pemberian soal latihan belum mampu menciptakan pembelajaran yang membuat siswa aktif.

Selain itu berdasarkan wawancara peneliti terhadap siswa di SMA Negeri 1 Banyuasin III dan SMA Negeri 3 Banyuasin III yang bernama Adiya Nabila, M. Radenal Murry, Rani Anggraini, dan Ziqral Naj Musyakib pada hari senin tanggal 11 Januari 2019 bahwa siswa sering mengalami kesulitan dalam mengerjakan soal biologi yang berbentuk klasifikasi berdasarkan wawancara tersebut diperoleh juga bahwa hasil belajar siswa masih rendah khususnya pada kompetensi memecahkan masalah yang berkaitan dengan pengklasifikasian ikan yang seharusnya dikuasai oleh siswa, selain itu guru masih belum menerapkan model pembelajaran berbasis inkuiri.

Berdasarkan uraian di atas, tampak bahwa rendahnya kemampuan berpikir kritis siswa cenderung disebabkan karena pelaksanaan pembelajaran yang belum optimal. Pelaksanaan pembelajaran masih cenderung bersifat konvensional yang didominasi dengan metode ceramah dan tanya jawab. Guru biologi umumnya setelah memberikan penjelasan tentang konsep kemudian dilanjutkan dengan soal latihan yang dipandu dengan LKPD. LKPD yang digunakan guru untuk meningkatkan dan memantapkan konsep biologi yang dimiliki siswa. Hasil analisis terhadap LKPD biologi yang digunakan oleh para guru SMA/MA di Banyuasin III menunjukkan bahwa LKPD tersebut masih kurang melatih kemampuan berpikir kritis siswa. LKPD tersebut hanya berisi ringkasan materi dan pertanyaan-pertanyaan yang cocok untuk mengukur penguasaan konsep biologi.

Berdasarkan hal di atas, maka perlu dicari solusi dengan mengembangkan LKPD yang mampu membantu dalam melatih dan menumbuhkan kemampuan berpikir kritis siswa. LKPD yang dipilih adalah LKPD yang menarik dan berpotensi memberdayakan kemampuan berpikir 
kritis adalah LKPD yang berbasis aktivitas, salah satunya LKPD berbasis inkuiri

Kegiatan pembelajaran yang baik idealnya tidak selalu berpusat pada guru (teacher centered), tetapi berpusat kepada siswa (student centered) yang menekankan pada aktivitas siswa untuk mencari dan menemukan sendiri jawaban dari suatu masalah yang dipertanyakan. Hal ini senada dengan apa yang diteliti oleh Wright (2011) yang mengemukakan bahwa student centered learning dapan menjadikan siswa semakin aktif sehingga dapat meningkatkan pemahaman mereka akan pelajarannya. Pembelajaran inkuiri membutuhkan salah satu perangkat pembelajaran yang mendukung pelaksanaan pembelajaran agar mempermudah terhadap pemahaman materi pembelajaran yang didapat yaitu LKPD.

Dalam penelitian ini, guna memperkaya referensi dan menempatkan posisi peneliti, maka peneliti memahami penelitian penelitian terkait yang pernah dikaji sebelumnya, seperti kajian yang pernah ditulis oleh Wahyudin et al. (2010) dengan judul Keefektifan Pembelajaran Berbantuan Multimedia Menggunakan Metode Inkuiri Terbimbing Untuk Meningkatkan Minat Dan Pemahaman, pada penelitian ini memfokuskan pada metode inkuiri terbimbing yg dapat meningkatkan minat dan pemahaman siswa. Di lain rujukan juga telah ditulis oleh Beladina, Suyitno, \& Khusni (2013) yang berjudul Keefektifan Model Pembelajaran Core Berbantuan LKPD Terhadap Kreativitas Matematis Siswa. Pada penelitian ini penulis juga mengkaji tentang LKPD namun belum berbasis Inkuiri.

Oleh karna itu perbedaan signifikan yang dapat dibandingkan dengan kajian kajian penelitian terdahulu, kajian peneliti kali ini lebih memfokuskan pada Pengembangan Lembar Kerja Peserta Didik (LKPD) Berbasis Inkuiri yang digunakan Pada Materi Pengklasifikasian Ikan. Kajian penelitian ini penting sekali untuk dihadirkan mengingat belum berkembangnya LKPD di sekolah menjadi LKPD yang inkuiri. Oleh karena itu, peneliti ingin melakukan pengembangan terhadap LKPD tersebut menjadi LKPD yang berbasis inkuiri

Menurut Ade Sanjaya (2011) sistem pembelajaran adalah suatu kombinasi terorganisasi yang meliputi unsur-unsur manusiawi, material, fasilitas, perlengkapan dan prosedur yang berinteraksi untuk mencapai suatu tujuan. Unsur manusiawi dalam sistem pembelajaran terdiri atas siswa, guru atau pengajar, serta orang-orang yang mendukung terhadap keberhasilan proses pembelajaran. LKPD digunakan untuk sebagai acuan atau memandu pelaksanaan kegiatan pembelajaran dan juga sebagai alat pembelajaran. Hal ini senada dengan pendapat Arafah et al. (2012). yang menyatakan bahwa LKPD berisi lembar kegiatan siswa dan soal-soal latihan, LKPD juga memuat 
ringkasan materi yang membantu dan mempermudah siswa dalam kegiatan pembelajaran LKPD berisi tugas dan langkah-langkah yang menuntun siswa mengelola pola pikir secara terarah. Peran guru sebagai fasilitator juga dapat dimaksimalkan. Dengan LKPD diharapkan siswa dapat belajar secara mandiri, memahami dan menjalankan suatu secara tertulis (Abdul, 2008). LKPD juga merupakan media pembelajaran yang dapat dikembangkan oleh guru di dalam kelas, yang dimana seorang berperan guru hanya berperan sebagai fasilitator dalam kegiatan pembelajaran. LKPD dapat disusun dan dikembangkan sesuai dengan kondisi dan situasi kegiatan pembelajaran yang akan di hadapi.

Pengajaran biologi melalui pendekatan inkuiri diharapkan dapat menjadi tempat bagi siswa untuk memecahkan masalah dan mempelajari dirinya sendiri serta alam sekitar. Sesuai dengan kurikulum 2013, inkuiri merupakan salah satu bentuk pendekatan ilmiah atau scientific approuch. Hal ini didukung juga oleh penelitian yang dikaji oleh Astuti \& Setiawan (2013), yang menyatakan bahwa pembelajaran dengan inkuiri terbimbing akan lebih mudah dilakukan siswa apabila dipadu dengan pembelajaran kooperative.

Pengembangan LKPD berbasis inkuiri mampu memotivasi dan memberi kesempatan kepada siswa dengan kemampuan tingkat atas dan siswa dengan kemampuan tingkat bawah untuk bersama-sama membangun konsep dalam belajar melalui asimilasi dan akomodasi yang diaktivasi melalui skemata awal yang dimilikinya, kegiatan diskusi dapat memunculkan konflik kognitif pada diri siswa sehingga siswa akan belajar dengan kualitas tingkat tinggi, kegiatan diskusi juga memberikan kesempatan kepada siswa untuk memperbaiki atau memperluas konsep awal yang dimilikinya. Hal ini juga senada dengan apa yang diungkapkan Beladina et al. (2013) tentang keefektifan penggunaan LKPD dalam pembelajaran. Selain itu, model ini mengakomodasi siswa agar mampu merencanakan, memantau dan mengevaluasi sendiri keberhasilan dari pembelajaran yang telah dilalui, sehingga siswa menjadi lebih mandiri dalam menghadapi situasi baru. Fitriani et al. (2017) juga menulis dalam artikelnya yang menyatakan bahwa penggunaan LKPD dapat membuat siswa menjadi lebih kreatif.

Pemberian penghargaan akan memberikan motivasi pada siswa untuk sadar akan tanggung jawabnya masing-masing untuk dapat memberikan kontribusi terbaik bagi kelompoknya, sehingga LKPD berbasis inkuiri dapat digunakan sebagai bahan ajar di sekolah sebagai penunjang proses berpikir, mandiri dan kesadaran belajar siswa. Fakta ini seirama dalam tulisan Latifah (2016) yang menyatakan bahwa penggunaan LKPD dapat dijadikan sebagai bahan ajar dalam proses pembelajaran. 
Selama ini proses pembelajaran biologi hanya menekankan pada pemahaman konsep (kognitif), dan kurangnya penerapan melalui hasil penemuan serta pemecahan masalah melalui kegiatan praktikum secara langsung sehingga siswa kurang terlatih. Terkait dengan ini, maka penulis mengembangkan lembar kerja peserta didik LKPD Inkuiri untuk meningkatkan kemampuan berpikir kritis siswa. Dengan pembelajaran ini diharapkan memberi kemudahan bagi siswa dalam mempelajari pokok bahasan pengklasifikasian ikan.

Untuk pemilihan materi pada penelitian ini, peneliti mengambil materi pengklasifikasian ikan. Hal ini dikarenakan pada materi ini siswa dapat memahami mengenai klasifikasi dan pemberian nama ganda (binomial namenclatur)pada materi klasifikasi diharapkan dapat memicu siswa berpatisipasi dalam menjaga kelestarian ikan. Hal ini senada dengan apa yang ditulis oleh Fitri (Astutik, 2015) dalam tulisannya yang menyatakan pentingnya pengenalan pola khas dari ikan untuk dapat mengklasifikasikan berdasarkan jenis. Sejalan dengan Faiqoh et al. (2017) juga menyatakan bahwa Ikan yang akan diklasifikasi harus dikelompokkan berdasarkan kemiripan, dihitung jumlahnya lalu dicatat jenis dan jumlahnya. Namun pada pembelajaran materi klasifikasi guru belum menerapkan model yang memungkinkan siswa aktif dan mandiri mencari informasi untuk memecahkan masalah dan menemukan konsep sementara. Berdasarkan angket yang telah disebarkan kepada semua siswa, menyatakan lebih tertarik dan termotivasi bila pembelajaran dilakukan secara nyata yaitu dengan mengamati secara langsung, penampilan, jumlah, sifat lain antar satu spesiesikan dengan spesies lain. Variasi dalam spesies ikan bersifat menurun. Dengan demikian, variasi dalam spesies dapat terjadi karena faktor keturunan atau genetika serta interaksinya terhadap lingkungan tempat tinggalnya. Variasi pada tingkat spesies ikan mudah diamati karena perbedaannya yang mencolok.

Variasi pada tingkat jenis disebabkan jumlah, bentuk, dan susunan kromosom (tempat terdapatnya gen) berbeda, faktor lingkungan, hibridisasi, dan mutasi kromosom. Pada materi pengklasifikasian ikan sebagai hewan air memiliki beberapa mekanisme fisiologis yang tidak dimiliki hewan darat. Perbedaan habitat menyebabkan perkembangan organ-organ ikan disesuaikan dengan kondisi lingkungannya, misalnya ikan sebagai hewan yang hidup di air, baik itu diperairan tawar maupun perairan laut menyebabkan ikan harus dapat mengetahui kekuatan maupun arah arus, karena ikan dilengkapi dengan organ yang disebut linea lateralis (Yushinta, 2004).

LKPD berbasis inkuiri dengan ujicoba untuk penyempurnaan produk yang dihasilkan untuk mengetahui kelayakan, dari sisi kepraktisan dan 
efektivitasnya. Akhirnya diharapkan LKPD berbasis inkuiri dapat memberikan hasil terbaik dalam mempelajari pengklasifikasian ikan sebagai kontribusi positif untuk memberdayakan kemampuan berpikir kritis bagi pembelajaran biologi di Indonesia. Berdasarkan uraian di atas, peneliti merasa tertarik untuk mengembangkan suatu bahan ajar pengklasifikasian ikan berbasis inkuiri berupa yang berupa produk LKPD. Sehingga peneliti merasa tertarik untuk melakukan penelitian dengan judul, Pengembangan Lembar Kerja Peserta Didik Berbasis Inkuiri Materi Pengklasifikasian Ikan di SMA Negeri Banyuasin III.

\section{METODOLOGI PENELITIAN}

Penelitian ini menggunakan metode penelitian dan pengembangan (Research and Development) (Sugiyono, 2008). Produk yang dikembangkan pada penelitian ini adalah LKPD berbasis inkuiri pada materi pengklasifikasian ikan menggunakan Model Prosedur pengembangan hasil adaptasi dari prosedur Borg \& Gall melalui sepuluh tahapan yaitu prosedur pengembangan menurut Sugiyono (2008) terdiri dari sepuluh langkah kerja diantaranya: 1) Penelitian dan pengumpulan informasi termasuk kajian literatur, observasi kelas dan membuat kerangka kerja penelitian; 2) melakukan pengumpulan data, mengidentifikasi, menyatakan tujuan, menentukan urutan untuk penelitian dan menguji kelayakan skala kecil; 3) mengembangkan LKPD; 4) validasi LKPD oleh para oleh ahli pengembangan LKPD, ahli bahasa, ahli media, ahli materi dan juga ahli perangkat pembelajaran; 5) Revisi LKPD; 6) Uji lapangan terbatas; 7) Revisi LKPD oleh peneliti; 8) Uji lapangan skala besar; 9) Revisi LKPD;10) Menghasilkan LKPD berbasis inkuiri yang layak digunakan di SMA. Pengembangan LKPD berbasis inkuiri tidak sampai pada tahap disseminate dan hanya memenuhi tahapan ke-sembilan yaitu revisi produk LKPD sesuai kebutuhan.

\section{HASIL PENELITIAN DAN PEMBAHASAN}

Pada penelitian pengembangan ini adalah menghasilkan bahan ajar berupa LKPD pembelajaran biologi berbasis inkuiri pada materi pengklasifikasian ikan. Berdasarkan identifikasi ini didapatkan beberapa potensi dan masalah yang terdapat di SMA Negeri 1 Banyuasin III dan SMA Negeri 3 Banyuasin III. Tahap observasi dan pemberian angket ditunjukan kepada peserta didik dan guru. 
mayoritas siswa belajar biologi dengan cara menghafal karena cara mengajar guru yang kurang menarik. Beberapa kali guru juga telah menerapkan model atau strategi dalam proses pembelajaran, namun siswa merasa belum terbiasa dalam kegiatan yang menyaji, menalar dan mencipta. Pembelajaran di kelas juga mewajibkan siswa memiliki buku pegangan wajib maupun LKPD. Siswa lebih banyak menggunakan buku dari penerbit yang ada di pasaran meskipun menurut siswa buku tersebut kurang menarik dan cukup mahal.

Hasil observasi terhadap guru menunjukkan bahwa selama ini pembelajaran sudah sesuai dengan KD, namun hasilnya belum memadai karena persiapan yang kurang dan siswa banyak yang tidak antusias dan aktif mengikuti. Selama pembelajaran sumber belajar yang digunakan adalah buku/LKPD yang ada dipasaran, namun karena hasilnya belum maksimal maka guru berharap adanya sumber belajar adanya sumber belajar seperti LKPD yang mampu memotivasi agar siswa lebih aktif. Melalui observasi ini siswa juga menggunakan bahwa selama pembelajaran guru pernah menggunakan metode atau strategi tertentu, tapi justru siswa kesulitan memahami materi yang disampaikan tersebut karena tidak menarik.

LKPD yang dikembangkan disusun berdasarkan pendekatan saintifik khususnya berbasis inkuiri. Penyusunan ini didasarkan pada langkah-langkah pembelajaran penemuan (inkuiri) yang nampak pada penyampaian materi yang terdapat di dalamnya. Langkah-langkah ini meliputi merumuskan masalah, merumuskan hipotesis, pengumpulan data, pengujian hipotesis, dan merumuskan kesimpulan. Penyusunan LKPD dengan langkah-langkah ini diharapkan dapat membawa siswa ke dalam pembelajaran dengan srategi inkuiri.

Dalam penelitian ini, draft awal LKPD berbasis inkuiri yang telah dibuat dinilai oleh para ahli bahasa, ahli materi, ahli perangkat pembelajaran, dan ahli media. Hasil validasi dosen ahli bahasa terhadap LKPD diperoleh keesuaian sebesar 87,5\% yang menunjukan kualifikasi sangat baik, aspek bahasa Indonesia yang baik dan benar, peristilahan yang sesuai dengan pokok bahasa sebesar $100 \%$ yang menunjukan kualifikasi sangat valid dari keseluruhan aspek bahasa dinyaatakan tidak perlu direvisi. Hasil validasi ahli materi LKPD diperoleh nilai aspek keakuratan materi yang relevan sebesar 77,7\% yang menunjukan kualifikasi valid, dari hasil validasi ahli materi dari materi, kesesuaian gambar, kesesuaian konsep, dan cara pengklasifikasian terhadap jenis ikan sudah menujukan hasil yang baik. Hal ini dilihat dari rata-ratayang sudah mencapai nilai $75 \%$ pada setiap aspek dari hasil tersebut dapat disimpulkan pada, materi sudah dapat di uji coba tetapi perlu perbaikan di 
beberapa aspek. Hasil validasi perangkat pembelajaran dan evaluasi diperoleh rata-rata 91,4\% yang menunjukan kualifikasi sangat valid. Berdasarkan hasil valiadi perangkat pembelajaran LKPD berbasis inkuiri dapat disimpulkanperangkat pembelajaran sudah mencapai semua aspek yang akan dikembangkan dalam LKPD inidapat dilakukan uji coba serta sangat layak untuk digunakan. Namun terdapat beberapa perbaikan. hasil validasi ahli media dan pengembangan lembar kerja peserta didik diperoleh rata-rata sebesar 63,2\% yang menunjukkan kualifikasi cukup valid, pada validasi ahli pengembangan desain dan keterbacaan media, desain keterbacaan LKPD sudah baik. Berdasarkan hasil validasi ahli media pemgembangan, LKPD ini layak untuk di uji coba melakukan beberapa perbaikan.

Penilaian oleh guru biologi SMA menjadi bahan evaluasi apakah LKPD berbasis inkuiri bisa digunakan atau tidak sebagai media pembelajaran. Guru biologi SMAmenilai dalam pelaksanaannya mudah dipakai. KemudahanLKPD dilihat dalam mudah keterpakaiannya dalam pembelajaran, dan dapat mensiasati keterbatasan waktu belajar di ruang laboratorium karena gambar yang terdapat pada LKPD sangat jelas. Terhadap usul dan saran yang disampaikan guru biologi tersebut diatas telah penulis lakukan. Membuat gambar ikan yang lebihjelas warnanya, mengoreksi lagikunci jawaban pada soal no.3,mengubah jenis dan ukuran fontdi latihan soal konsisten dengan font yang dipakai di LKPD, mengurangi ukuran panjangLKPD berbasis inkuiri, menambahkan materi tentang pengklasifikasian ikan sesuai dengan kompetensi dasar, serta menambahkan soal pengayaan.

Setelah produk di cetak, maka langkah selanjutnya adalah uji coba lapangan baik skala kecil maupun skala besar. Tujuan uji coba untuk mengetahui/menguji kepraktisan dan efektivitas LKPD. Pengujian kepraktisan menunjukkan kemudahan dan kesenangan oleh pengguna saat menggunakan LKPD dalam proses pembelajaran, dalam hal ini adalah siswa. Pengujian kepraktisan ini meliputi aspek kemudahan dalam penggunaan, manfaat yang didapat dan mengatasi keterbatasan waktu dalam hal mempelajari pengklasifikasian ikan. Pengujian ini dilaksanakan dalam uji coba skala kecil dan skala besar.

Hasil uji kelompok kecil diperoleh rata-rata semua capaian sebesar 81,7\% menunjukan kualitas sangat valid dan dinyatakan tidak perlu direvisi secara keseluruhan, tetapi berdasarkan hasil uji lapngan terbatas disimpulkan bahwa LKPD berbasis inkuiri masih diperlukan perbaikan pada cetakan kata/kalimat, kejelasan gambar dan keterangan gambar yang harus dilengkapi. Hasil uji kelompok besar diperoleh rata-rata semua capaian sebesar 87,25\%, menunjukan kualitas sangat valid dan dinyatakan tidak perlu revisi, tetapi 
berdasarkan uji lapangan skala besar disimpulkan bahwa LKPD berbasis inkuiri masih diperlukan perbaikan pada beberapa kalimat, kejelasan gambar dan keterangan gambar yang perlu dilengkapi.

Setelah produk diperbaiki, selanjutnya dilakukan pengujian kembali dengan hasil uji kelompok kecil diperoleh rata-rata semua capaian sebesar 93,5\% menunjukan kualitas sangat valid dan dinyatakan tidak perlu direvisi secara keseluruhan, tetapi berdasarkan hasil uji lapangan terbatas disimpulkan bahwa LKPD berbasis inkuiri masih diperlukan perbaikan pada cetakan kata/kalimat, kejelasan gambar dan keterangan gambar yang harus dilengkapi. Hasil uji kelompok besar diperoleh rata-rata semua capaian sebesar 87,7\%, menunjukan kualitas sangat valid dan dinyatakan tidak perlu revisi, tetapi berdasarkan uji lapangan skala besar disimpulkan bahwa LKPD berbasis inkuiri masih diperlukan perbaikan pada beberapa kalimat, kejelasan gambar dan keterangan gambar yang perlu dilengkapi.

Selanjutnya untuk melihat efektivitas penggunaan LKPD berbasis inkuiri dalam proses pembelajaran, maka dilakukan dengan menganalisis nilai tes awal (pretest) dan nilai tes akhir (posttest). Analisis efektivitas menggunakan rumus $\mathrm{N}$-gain. Hasil analisis dapat dijelaskan sebagai berikut:

Tabel 1 Perhitungan N-Gain.

\begin{tabular}{|c|c|c|c|c|c|c|c|}
\hline No. & Nama Siswa & $\begin{array}{l}\text { Pre } \\
\text { Test }\end{array}$ & $\begin{array}{l}\text { Pos } \\
\text { Test }\end{array}$ & $\begin{array}{l}\text { Perhitungan } \\
\text { N-Gain }\end{array}$ & $\begin{array}{l}\text { Nilai } \\
\text { Max }\end{array}$ & Rentang & Kriteria \\
\hline 1 & Adelia & 40 & 90 & 100,00 & 100 & $\begin{array}{l}0,3<\mathrm{N}- \\
\text { gain<0,7 }\end{array}$ & Tinggi \\
\hline 2 & Aji Juliana & 50 & 100 & 1,00 & 100 & $\begin{array}{l}0,3<\mathrm{N}- \\
\text { gain }<0,7\end{array}$ & Tinggi \\
\hline 3 & Ajie Mitullah & 50 & 100 & 1,00 & 100 & $\begin{array}{l}0,3<\mathrm{N}- \\
\text { gain }<0,7\end{array}$ & Tinggi \\
\hline 4 & Angga Arizki & 70 & 100 & 1,00 & 100 & $\begin{array}{l}0,3<\mathrm{N}- \\
\text { gain }<0,7\end{array}$ & Tinggi \\
\hline 5 & Anggun Sisasmi & 50 & 90 & 0,80 & 100 & $\begin{array}{l}0,3<\mathrm{N}- \\
\text { gain }<0,7\end{array}$ & Tinggi \\
\hline 6 & Ayu Dila & 40 & 90 & 0,83 & 100 & $\begin{array}{l}0,3<\mathrm{N} \\
\text { gain }<0,7\end{array}$ & Tinggi \\
\hline 7 & Dani Syawiran & 60 & 90 & 0,75 & 100 & $\begin{array}{l}0,3<\mathrm{N}- \\
\text { gain }<0,7\end{array}$ & Tinggi \\
\hline 8 & Dendika Istya & 50 & 90 & 0,80 & 100 & $0,3<\mathrm{N}$ & Tinggi \\
\hline
\end{tabular}




\begin{tabular}{|c|c|c|c|c|c|c|c|}
\hline & Pratama & & & & & gain $<0,7$ & \\
\hline 9 & Dika Agustian & 50 & 90 & 0,80 & 100 & $\begin{array}{l}0,3<\mathrm{N} \quad- \\
\text { gain }<0,7\end{array}$ & Tinggi \\
\hline 10 & $\begin{array}{ll}\text { Dita } & \text { Tarisma } \\
\text { Wijaya } & \end{array}$ & 50 & 90 & 0,80 & 100 & $\begin{array}{l}0,3<\mathrm{N} \quad- \\
\text { gain }<0,7\end{array}$ & Tinggi \\
\hline 11 & Ema Pertiwi & 50 & 80 & 0,60 & 100 & $\begin{array}{l}0,3<\mathrm{N} \quad- \\
\text { gain }<0,7\end{array}$ & Sedang \\
\hline 12 & Herrinda Rahayu & 40 & 90 & 0,83 & 100 & $\begin{array}{l}0,3<\mathrm{N} \quad- \\
\text { gain }<0,7\end{array}$ & Tinggi \\
\hline 13 & Hilda Rahmawati & 40 & 90 & 0,83 & 100 & $\begin{array}{l}0,3<\mathrm{N} \quad- \\
\text { gain }<0,7\end{array}$ & Tinggi \\
\hline 14 & Intan Anggraini & 50 & 90 & 0,80 & 100 & $\begin{array}{l}0,3<\mathrm{N} \quad- \\
\text { gain }<0,7\end{array}$ & Tinggi \\
\hline 15 & Intan Olipiya & 50 & 90 & 0,80 & 100 & $\begin{array}{l}0,3<\mathrm{N} \quad- \\
\text { gain }<0,7\end{array}$ & Tinggi \\
\hline 16 & Kevin Satria & 60 & 90 & 0,75 & 100 & $\begin{array}{l}0,3<\mathrm{N} \quad- \\
\text { gain }<0,7\end{array}$ & Tinggi \\
\hline 17 & $\begin{array}{ll}\text { M. } & \text { Angga } \\
\text { Saputra } & \end{array}$ & 70 & 100 & 1,00 & 100 & $\begin{array}{l}0,3<\mathrm{N} \quad- \\
\text { gain }<0,7\end{array}$ & Tinggi \\
\hline 18 & Maulana & 50 & 80 & 0,60 & 100 & $\begin{array}{l}0,3<\mathrm{N} \quad- \\
\text { gain }<0,7\end{array}$ & Sedang \\
\hline 19 & $\begin{array}{l}\text { Nur } \\
\text { Azmihidayati }\end{array}$ & 50 & 90 & 0,80 & 100 & $\begin{array}{l}0,3<\mathrm{N} \quad- \\
\text { gain }<0,7\end{array}$ & Tinggi \\
\hline 20 & Rani Anggraini & 50 & 90 & 0,80 & 100 & $\begin{array}{l}0,3<\mathrm{N} \quad- \\
\text { gain }<0,7\end{array}$ & Tinggi \\
\hline 21 & Rika Apri Lia & 50 & 90 & 0,80 & 100 & $\begin{array}{l}0,3<\mathrm{N} \quad- \\
\text { gain }<0,7\end{array}$ & Tinggi \\
\hline 22 & Soleha & 50 & 100 & 1,00 & 100 & $\begin{array}{l}0,3<\mathrm{N} \quad- \\
\text { gain }<0,7\end{array}$ & Tinggi \\
\hline 23 & $\begin{array}{l}\text { Syraeni Setawan } \\
\text { Syahputri }\end{array}$ & 60 & 90 & 0,75 & 100 & $\begin{array}{l}0,3<\mathrm{N} \quad- \\
\text { gain }<0,7\end{array}$ & Tinggi \\
\hline 24 & Winda Sawitri & 70 & 90 & 0,67 & 100 & $\begin{array}{l}0,3<\mathrm{N} \quad- \\
\text { gain }<0,7\end{array}$ & Sedang \\
\hline 25 & $\begin{array}{ll}\text { Ziqral } & \text { Naj } \\
\text { Musyakib } & \\
\end{array}$ & 40 & 80 & 0,67 & 100 & $\begin{array}{l}0,3<\mathrm{N} \quad- \\
\text { gain }<0,7\end{array}$ & Sedang \\
\hline & Jumlah & 1290 & 2270 & 119,48 & 2500 & & \\
\hline & Rata-rata & 51,6 & 90,8 & 4,78 & 100 & & \\
\hline
\end{tabular}




\section{KESIMPULAN}

Berdasarkan hasil pengembangan dan pembahasan yang telah disajikan pada bab sebelumnya maka yang dapat disimpulkan sebagai berikut. Kevalidan LKPD berbasis inkuiri diuji melalui tahapan expert judgment validity yang dilakukan oleh validator media, validator materi, validator bahasa, dan validator perangkat pembelajaran yang di dalamnya terdapat aspek materi/substansi, aspek konstruksi, dan aspek bahasa. Hasil validasi dosen ahli menunjukkan bahwa LKPD berbasis inkuiri memiliki kualifikasi validasi baik.

Pengujian kepraktisan menunjukkan kemudahan dan kesenangan oleh pengguna saat menggunakan LKPD dalam proses pembelajaran, dalam hal ini adalah siswa. Pengujian kepraktisan ini meliputi aspek kemudahan dalam penggunaan, manfaat yang didapat dan mengatasi keterbatasan waktu dalam hal mempelajari pengklasifikasian ikan. Selain dari pada itu dilihat dari saran dan komentar yang diberikan oleh siswa dan guru terhadap LKPD berbasi inkuiri terbilang positif. Penerapan LKPD berbasis inkuiri ini juga pernah dilakukan oleh Annafi (2016) yang mana menunjukkan hasil yang positif juga.

Penilaian keefektivan terhadap penggunaan LKPD apabila memberikan pengaruh yang positif yaitu tujuan pembelajaran tercapai dengan perolehan hasil belajar siswa. Pertama, diperoleh melalui peningkatan hasil belajar siswa dengan analisis data nilai tes akhir dan tes awal. Kedua, terjadinya peningkatan nilai tes akhir siswa melebihi atau sama dengan standar Kriteria Ketuntasan Minimal (KKM). 


\section{DAFTAR PUSTAKA}

Abdul, M. (2008). Perencanaan Pembelajaran, Mengembangkan Standar Kompetensi Guru. Jakarta: PT. Rosda Karya.

Ade Sanjaya. (2011). Model-model Pembelajaran,. Jakarta: Bumi Aksara.

Annafi, N. (2016). PENGARUH PENERAPAN LKPD BERBASIS INKUIRI TERBIMBING DI MAN 1 KOTA BIMA. Journal of Educational Science and Technology (EST), 2(2), 98-104. https:/ / doi.org/10.26858/est.v2i2.2097

Arafah, S. F., Ridlo, S., \& Priyono, B. (2012). PENGEMBANGAN LKS BERBASIS BERPIKIR KRITIS PADA MATERI ANIMALIA. 7.

Astuti, Y., \& Setiawan, B. (2013). PENGEMBANGAN LEMBAR KERJA SISWA (LKS) BERBASIS PENDEKATAN INKUIRI TERBIMBING DALAM PEMBELAJARAN KOOPERATIF PADA MATERI KALOR. Jurnal Pendidikan IPA Indonesia, 2(1). https:/ / doi.org/10.15294/jpii.v2i1.2515

Astutik, F. (2015). SISTEM PENGENALAN KUALITAS IKAN GURAME DENGAN WAVELET, PCA, HISTOGRAM HSV DAN KNN. Lontar Komputer: Jurnal Ilmiah Teknologi Informasi. Diambil dari https:/ / ojs.unud.ac.id/index.php/lontar/article/view/16730

Beladina, N., Suyitno, A., \& Khusni, K. (2013). KEEFEKTIFAN MODEL PEMBELAJARAN CORE BERBANTUAN LKPD TERHADAP KREATIVITAS MATEMATIS SISWA. Unnes Journal of Mathematics Education, 2(3). https://doi.org/10.15294/ujme.v2i3.3363

Borg, W. R., \& Gall, M. D. (1971). Educational research: an introduction. McKay. Dimyati. (1999). Belajar dan pembelajaran. Rineka Cipta.

Faiqoh, E., Wiyanto, D. B., \& Astrawan, I. G. B. (2017). Peranan Padang Lamun Selatan Bali Sebagai Pendukung Kelimpahan Ikan di Perairan Bali. Journal of Marine and Aquatic Sciences, 3(1), 10-18. https:/ / doi.org/10.24843/jmas.2017.v3.i01.10-18

Fitriani, N., Gunawan, G., \& Sutrio, S. (2017). Berpikir Kreatif Dalam Fisika Dengan Pembelajaran Conceptual Understanding Procedures (CUPs) Berbantuan LKPD. Jurnal Pendidikan Fisika Dan Teknologi, 3(1), 24-33. https:/ / doi.org/10.29303/jpft.v3i1.319

Kemendikbud. (2013). Permedikbud Nomor 65 Tahun 2013 Tentang Standar Proses. Jakarta: Kemendikbud. Diakses pada tanggal 29 Mei 2018. Kemendikbud.

Latifah, S. (2016). Pengembangan Lembar Kerja Peserta Didik (LKPD) Berorientasi Nilai-Nilai Agama Islam melalui Pendekatan Inkuiri 
Terbimbing pada Materi Suhu dan Kalor. Jurnal Ilmiah Pendidikan Fisika Al-Biruni, 5(1), 43-51. https:/ / doi.org/10.24042/jpifalbiruni.v5i1.104

Sugiyono. (2008). Metode penelitian pendidikan: (pendekatan kuantitatif, kualitatif dan $R \& D)$. Alfabeta.

Wahyudin, -, Sutikno, -, \& Isa, A. (2010). KEEFEKTIFAN PEMBELAJARAN BERBANTUAN MULTIMEDIA MENGGUNAKAN METODE INKUIRI TERBIMBING UNTUK MENINGKATKAN MINAT DAN PEMAHAMAN SISWA. Jurnal Pendidikan Fisika Indonesia, 6(1). https:/ / doi.org/10.15294/jpfi.v6i1.1105

Wright, G. B. (2011). Student-Centered Learning in Higher Education. International Journal of Teaching and Learning in Higher Education, 23(1), 9297.

Yushinta, F. (2004). Fisiologi lkan. Dasar Pengembangan Teknik Perikanan. Jakarta: Rineka Cipta. 